\title{
SPIRITUALITY AS “GOOD CHRISTIAN CITIZENSHIP" IN THE PASTORAL EPISTLES?
}

\begin{abstract}
Dibelius, in his commentary on the Pastoral Epistles, suggested that they represented a way-of-being in the world resulting from the delay of the parousia. As such they advocate a form of spirituality which can best be described as "good Christian citizenship". This paper, drawing on both Taylor's understanding of the "social imaginary" and Waaijman's understanding of spirituality, examines Dibelius' contention by revisiting the concept of eusebeia (godliness/piety), which is prevalent in the Pastorals, in the light of the lived experience of pagans, Jews and Christians in first-century Ephesus.
\end{abstract}

\section{INTRODUCTION}

The Pastoral Epistles are not the biblical texts one would instinctively turn to for a discussion on spirituality. When examining the New Testament one would be far more likely to discuss the spirituality that Jesus advocates in the Synoptic Gospels, or the Johannine Jesus' concept of eternal life or the Pauline emphasis on participation "in Christ". The Pastorals have been described as a fading of the Pauline vision of charismatic community in which "the experience of the Christ-Spirit has lost its vitality" (Dunn 1975:349), or as advocating a form of Christianity which has to conform itself to wider society in the light of the delay of the parousia (Dibelius \& Conzelmann 1972). In the light of such negative evaluations this essay forms an initial enquiry, as part of a projected, book-length project, into the spirituality of the Pastoral Epistles. In this larger project I want to use Charles Taylor's concept of spirituality as the lived experience of humanity in three broad dimensions: a place of fullness to which people orient themselves either morally or spiritually; a sense of disorientation

Dr Lloyd K. Pietersen, Senior Lecturer and Research Co-ordinator in New Testament Studies, Department of Humanities, University of Gloucestershire. E-mail: Ipietersen@glos.ac.uk

Acta Theologica

2011 Suppl 15: 154-166

ISSN 1015-8758

http://dx.doi.org/10.4314/actat.v31i1S.9

(c) UV/UFS

<http://www.uovs.ac.za/ActaTheologica> 
or ennui indicating the absence of fullness; and a routinised middle ground in which most of life is conducted between these two extremes (Taylor 2007:414). It remains to be seen whether the elements of the Pastorals highlighted by commentators such as Dunn and Dibelius should be interpreted in the way they do or whether, as indicative of Taylor's "middle ground", these elements actually form an essential part of a vibrant post-Pauline spirituality. Taylor's understanding of spirituality will be used to investigate as far as possible the lived experience of pagans, Jews and Christians in Ephesus and Crete in the first century CE in order to elucidate more clearly the spirituality advocated in the Pastorals. In this investigation I shall aim to tease out different notions of "the good life" in the fundamentally "enchanted world" of the first century. ${ }^{1}$

This paper takes issue with the view famously put forward by Dibelius that the Pastorals' notion of "the good life" can more or less be equated with that of the wider Graeco-Roman society. To contest this position I will examine the concept of eusebeia (piety/godliness) in pagan and Jewish literature and compare this with its use in the Pastorals.

\section{DIBELIUS' CONCEPT OF “THE IDEAL OF GOOD CHRISTIAN CITIZENSHIP"}

Dibelius, in his commentary on the Pastoral Epistles, has an excursus on "The Ideal of Good Christian Citizenship" when commenting on 1 Timothy 2:1-7 (Dibelius \& Conzelmann 1972:37-41). For Dibelius, the author promotes "an ideal of a peaceful life" and "wishes to become part of the world". This is due to a fundamental reorientation towards the world in the light of the delay of the Parousia. In this climate the Pastorals and certain other strands of the New Testament testify "to the presence of loyalty to the state and its officials". ${ }^{2}$ In the Pastorals prayer is required for the pagan authorities, Hellenistic virtues such as eusebeia and semnotēs (dignity/solemnity) are espoused and Christians are expected to behave with sobriety and prudence. The family ethic in the Pastorals, according to Dibelius, goes beyond the traditions of the household code and is "[t]he clearest sign of a Christianization of the world". This whole ethos and orientation to the world differs markedly from Paul and displays none of Paul's concerns about the predicament from which Christians are saved by faith. Interestingly, Dibelius does admit that the description concerning being prepared for death in 2 Timothy goes beyond this ideal of Christian citizenship

1 Taylor's project, in part, seeks to explicate the reasons for moving away from the "enchanted world ... of spirits, demons, and moral forces which our ancestors lived in" (Taylor 2007:26) to our current, disenchanted secular age.

2 Dibelius \& Conzelmann (1972:37) citing, in addition to 1 Timothy 2:2, Romans 13:1-7; 1 Peter 2:14, 17; Titus 3:1 and Acts generally. 
and should not be overlooked (Dibelius \& Conzelmann 1972:40). However, not much is made of this in the subsequent commentary. So, according to Dibelius, the spirituality advocated in the Pastorals is one in which human flourishing is basically synonymous with conformity to the virtues valued by the wider Graeco-Roman society. Spirituality is "good Christian citizenship" with its upholding of the household code and advocacy of loyalty to the state.

At first reading, Dibelius' comments appear persuasive. There is a major emphasis on sobriety, moderation, soundness of mind and sound teaching. ${ }^{3}$ Prayer is urged for those occupying positions of authority in the state so that the church "may lead a quiet and peaceable life in all godliness and dignity" (1 Tim 2:1-2). Eusebeia, a key word in the Pastorals (1 Tim 2:2; 3:16; 4:7, 8; $6: 3,5,6,11 ; 2$ Tim 3:5; Titus 1:1), is specifically linked to the peaceful life in $1 \mathrm{Tim}$ 2:2. Believers are urged "to live lives that are self-controlled, upright and godly (eusebōs)" in the present age (Titus 2:12). An episkopos "must be well thought of by outsiders" (1 Tim 3:7) and the rich are not urged to dispose of their wealth but are encouraged "to do good, to be rich in good works, generous and ready to share" (1 Tim 6:17-18). Furthermore, the household codes appear to endorse the values of the wider society, particularly as far as women and slaves are concerned (1 Tim 2:9-15; 6:1-2).

However, 2 Timothy 3:12, citing the example of Paul's own persecutions, insists that "all who want to live a godly (eusebōs) life in Christ Jesus will be persecuted". This passage does not fit easily into Dibelius' notion of "good Christian citizenship". The prayer for a quiet and peaceable life lived in all eusebeia of 1Timothy 2:2 is offered in the full knowledge that such a eusebōs life is likely to lead to persecution. ${ }^{4}$ Thus the eusebeia of the Pastorals cannot be so easily equated with that of the wider society and it is this concept of eusebeia that I wish to investigate. But first, I want to draw on Taylor's concept of the "social imaginary" to elucidate the background against which the concept of eusebeia should be understood.

3 sōphroneō Titus 2:6; sōphronizō Titus 2:4; sōphronismos 2 Timothy 1:7; sōphronos Titus 2:12; sōphrosynē 1 Timothy 2:9, 15; sōphrōn 1 Timothy 3:2; Titus 1:8; 2:2, 5; hygiainō 1 Timothy $1: 10 ; 6: 3 ; 2$ Timothy $1: 13 ; 4: 3$; Titus 1:9, 13; 2:1, 2; hygiēs Titus 2:8.

4 In my view it is legitimate, in this context, to read 2 Timothy 3:12 in the light of 1 Timothy 2:2 and vice-versa as Dibelius himself regards the Pastorals as a literary corpus. See, especially, Dibelius \& Conzelmann (1972:5-8) and Marshall (1999:1-2). 


\section{THE "SOCIAL IMAGINARY"}

Taylor makes it clear that his concept of the "social imaginary" is not the same as social theory. His concept concerns the ways in which ordinary people imagine their world and this is usually "carried in images, stories, legends, etc." (Taylor 2007:172). This view of society is shared by the majority, if not the whole society. By its very nature it cannot be adequately explicitly enunciated and hence Taylor's use of the term "imaginary". An important aspect of this background concerns a sense of moral order and this is significant for our purposes as we shall see below that eusebeia conveys the sense of conformity to moral order. Thus Dibelius' question can be rephrased, using Taylor's terminology, as "to what extent do the Christian communities at Ephesus and Crete addressed by the Pastorals reflect the social imaginary of the wider society and to what extent do they transform or contradict it". Of course our only access to this social imaginary is through the images, stories and legends conveyed in extant texts.

\section{EPHESUS IN THE FIRST CENTURY CE $^{5}$}

Trebilco and I both argue for Ephesus as the intended destination of 1 and 2 Timothy even if these letters are pseudepigraphical. ${ }^{6}$ Ephesus experienced tremendous growth during the reign of Augustus and numerous monumental public buildings were erected during the first and second centuries $C E$. It was the capital of the Roman province of Asia and received the title "the first and greatest metropolis of Asia" which is found on inscriptions of this period. Its population is estimated at between 200,000 and 250,000 making it the third largest city after Rome and Alexandria. The city, located at the intersection of a number of major land and sea routes, was a major centre of international trade.

In common with other large cities in the East, Ephesus was host to the worship of numerous Graeco-Roman and Anatolian deities. The enchanted world of deities and demons is absolutely central to the lived experience of ordinary people in the first century. This can sometimes be overlooked when attention is focused on literature produced by the educated elite. Although there is no doubt that a significant amount of demythologisation of the old Olympian gods had taken place within intellectual circles by the first century, rendering the concept of respect for the gods as more or less synonymous with conformity to the moral order, this does not necessarily reflect the social imaginary of ordinary people. The magical papyri provide abundant evidence for the popularity of magic, mystery cults and astrological beliefs in this

5 For this section I am indebted to Trebilco (2004).

6 Trebilco (2004:206-9); Pietersen (2004:112-13). 
period. ${ }^{7}$ Furthermore, Ephesus itself had a reputation as a centre of magical arts. It gave its name to the Ephesia grammata, six magical terms thought to be words of power. Whatever one makes of the historicity of Acts 19:11-20 it is significant that Luke sets Paul's encounter with magical practices in Ephesus. Luke goes on to describe how the success of Paul's mission threatened the livelihood of artisans trading on the reputation of Artemis (Acts 19:21-41). The temple of Artemis of Ephesus featured in many lists of the seven wonders of the ancient world. The bond between Artemis and the city was so strong that Oster can summarise it as follows:

[T] he quintessence of Artemis was forever related to the well being of Ephesus. Notwithstanding the individualistic and personal significance of the goddess, the principal force of her cult was upon the interrelated components of the city's urban life, e.g., the civic, economic, educational, patriotic, administrative, and commercial facets ... There was no other Graeco-Roman metropolis in the Empire whose "body, soul, and spirit" could so belong to a particular deity as did Ephesus to her patron goddess Artemis (Oster 1990:1728).

In Taylor's terms, the social imaginary of Ephesian society would have been dominated by Artemis. Significantly, Artemis:

was acclaimed as Lady (Kyria), Saviour (Sōteira), a heavenly goddess (ouranios theos Artemis Ephesia), and the Queen of the Cosmos (basileis kosmou). She was also described as greatest (megistē), great (megalē), holiest (hagiōtatē), and most manifest (epiphanestatē) (Trebilco 2004:22).

Although the imperial cult also had a significant role in the city, with a provincial cult established there by Domitian in the eighties CE, in my view its importance as background for the Pastoral Epistles has been overstated. ${ }^{8}$ The cult certainly is important in connection with the general background of pagan worship - imperial images have been found in private homes and there were a considerable number of imperial statues - but until the time of Domitian, when the city was known as "twice neokoros", it does not have the same significance as the Artemis cult for the city. ${ }^{9}$ Arnold concurs, noting that there are no examples of votive offerings indicating fulfilled prayer involving any

7 See Arnold (1989:14-20).

8 Contra Gill (2008).

9 It is significant that Luke only mentions Artemis and not the imperial cult in Acts 19. This may be due to Luke's apologetic purposes but he is quite capable elsewhere of reporting the accusation against Paul and Silas that they "are acting contrary to the decrees of the emperor, saying that there is another king named Jesus" (Acts 17:7). 
emperors on their own. He concludes his discussion of the imperial cult in Asia Minor as follows:

The ruler cult offered no protection or safeguard to its adherents from the threatening evil "powers". Those seeking salvation, healing, oracular advice, or genuine religious experience would turn elsewhere. ${ }^{10}$

\section{LIVED EXPERIENCE IN EPHESUS}

As stated above, any discussion of the lived experience of ordinary people in Ephesus has to take into account the enchanted world of deities and demons, the role of magic in the city and, in particular, the pervasive influence of the Artemis cult. In addition, of course, as the third city in the Roman Empire, Ephesians would be captured by the social imaginary of the wider GraecoRoman world. For this paper I will restrict my discussion of this lived experience to the notion of eusebeia as this term is significant for Dibelius' construal of the Pastorals' advocacy of "good Christian citizenship".

\subsection{Pagans}

In the most general sense the eusebeia word group (eusebeia, eusebēs, eusebeō) denotes respect for the orders of life, especially in connection with family and government. But as these orders, in an enchanted world, are seen as under the protection of the gods, the word group increasingly comes to refer to the proper attitude of devotion to the gods (piety) and to their worship. Many inscriptions praise people for their eusebeia towards the gods and this appears to be synonymous with the provision of funds to enhance the work of the particular cult, especially in terms of furnishing its temples. This devotion is often portrayed as "reverent and wondering awe at the lofty and pure world of the divine, its worship in the cultus, and respect for the orders sustained by it". ${ }^{11}$ It does not, however, appear to feature in magical contexts. There are only three references in the Greek magical papyri. ${ }^{12}$ Nevertheless, there is a close link between the cult of Artemis and magical practices at Ephesus ${ }^{13}$ and the term eusebeia is certainly closely connected with Artemis. An inscription dated to 104 CE describes someone's "reverence [eusebeian] for the most

10 Arnold (1989:38), my emphasis.

11 W. Foerster, TDNT 7:178.

12 PGM IV.684, "[b]ut to me, who am pious (eusebel) and god-fearing (theosebel), you send health and soundness of being". PGM XIII.717, "Always sacrifice to this [god] in this way and offer your pious devotions (eusebeias), for thus he will hear you". Also "piously" (eusebōs) occurs in the fragment PGM XXXVII.22.

13 See Arnold (1989:20-28). 
manifest goddess Artemis". ${ }^{14}$ The wardens of the mysteries of the Artemis cult (the Kouretes) were titled eusebeis. ${ }^{15}$

Thus, in an Ephesian setting, eusebeia and its cognates would have been most readily understood in connection with Artemis. The life of the city was bound up with devotion to the goddess. Two major festivals were held annually at Ephesus in honour of Artemis. The Artemisia lasted for a whole month and "probably included athletics, theatrical and musical contributions" (Trebilco 2004:24). The second festival celebrated the nativity of Artemis and is likely to have been the most significant celebration in the liturgical calendar of Ephesus. In addition, it is estimated that a major procession involving 31 statues and images, nine of which were of Artemis, took place fortnightly in the city (Trebilco 2004:28). It is highly likely, therefore, that the language of "piety" in an Ephesian context would have been understood primarily as devotion to Artemis.

\subsection{Jews}

Although no synagogue has yet been discovered in Ephesus, evidence from decrees preserved in both Josephus and Philo indicate that there was a sizeable Jewish community in Ephesus at the time of the Pastorals. ${ }^{16}$ For Jews the production of the LXX was a conscious attempt to reinterpret their faith in terminology understandable to their contemporaries. Within the LXX eusebeia occurs 59 times (4 times in canonical books [Prov 1:7; 13:11; Isa 11:2; 33:6]; 5 times in the Apocrypha [1 Esdr 1:23; Wis 10:12; Sir 49:3; 2 Macc 3:1; 12:45], 3 times in 3 Maccabees and 47 times in 4 Maccabees), eusebēs occurs 39 times (10 times in canonical books; Jdth 8:31; 2 Macc $1: 19 ; 12: 45 ; 15$ times in Sirach and 11 times in 4 Maccabees) and eusebeō 5 times (Sus 63; 4 Macc 9:6; 11:5, 23; 18:1). These statistics demonstrate the concentration of the word group in deutero-canonical writings. A close examination of the contexts suggests that the word group conveys the notion of covenant loyalty, the knowledge and fear of Yahweh, and the behavioural response that such knowledge and fear engenders. ${ }^{17}$ Towner concludes his discussion as follows:

This combination of components in the eusebeia word group (the knowledge of God, fear of the Lord and requisite conduct) seen in Hellenistic Jewish writings, and not secularization, determines its meaning in NT use (Towner 2006:173).

14 IvEph. 27.344-5; see also Horsley (2006:74-82).

15 See, for example, Llewelyn \& Kearsley (2007:196).

16 See the discussion in Trebilco (2004:38-43).

17 See Towner (2006:172-73). 
Towner, following the discussion of eusebeia by both Quinn (1990:282-91) and Marshall (1999:135-44), rightly draws attention to the significance of the word group in Hellenistic Judaism for an understanding of the use of eusebeia and cognates in the Pastorals. However, the discussion in the commentaries has focused on the use of these terms in Graeco-Roman literature and in Hellenistic Judaism without paying sufficient attention to the specifically Ephesian context of 1 and 2 Timothy. Furthermore, no attention has been given to the significant evidence that we have for Jewish syncretistic practices in the first century. This is important given the undoubtedly Jewish elements to the teaching opposed by the Pastorals. ${ }^{18}$ There are several strands of evidence that point to Jewish involvement in magical practices. First, there are a number of amulets and incantations which contain predominantly Jewish material with the names of other gods added. A number of these have been discovered in the region of Ephesus. Second, the Book of Razi'el contains a miscellaneous collection of Jewish magical treatises some of which date back to Talmudic times. Third, there is the magical manual, the Sword of Moses which may contain material going back to the first four centuries CE. Fourth, it is widely agreed that behind the Testament of Solomon, which also contains early material, lies a Jewish encyclopaedia of magic. Finally, Sefer ha-Razim, or the "Book of Mysteries", dated to the fifth or sixth century CE but containing much earlier folk materials, has some striking similarities with material preserved in $P G M .{ }^{19}$ I suggest, therefore, that a combination of traditional Hellenistic Jewish concepts of eusebeia outlined above, Ephesian understanding of eusebeia as devotion to Artemis, and other notions derived from magical practices would have informed the social imaginary of ordinary Jews in Ephesus. ${ }^{20}$

\subsection{Christians}

Christian spirituality can best be understood using Waaijman's definition of spirituality as "the divine-human relational process ... which is viewed as a layered process of transformation" (2002:425). Waaijman emphasises four key divine-human relational moments: creation; humanity as God's representative; humanity as pupils of God; and humanity as covenant partners (2002:44654). In the context of the Pastorals, with their clear emphasis on teaching and instruction, it is the third of these relational aspects that is primarily in view. For Waaijman the process of transformation consists of five layers: from non-being to being; from being malformed to being re-formed; becoming conformed to

181 Timothy $1: 6-11$; Titus $1: 10,14 ; 3: 9$.

19 For a short description of all these, and a detailed discussion of Sefer ha-Razim, see Alexander (2003).

20 This suggestion will be pursued in much more detail in the forthcoming monograph. 
Christ; transformation in love; and final transformation in glory (2002:455-81). Although all layers are referred to in the Pastorals (e.g. 1 Tim 6:13a; Titus 3:35; 2 Tim 1:13-14; 1 Tim 6:18-19; 2 Tim 4:8), eusebeia as devotion to Christ focuses on the third process of conformation. We can see this by examining eusebeia and its cognates in 1 and 2 Timothy. The word group is used 11 times in these two letters (1 Tim 2:2; 3:16; 4:7, 8; 5:4; 6:3, 5, 6, 11; 2 Tim 3:5, 12). 1 Timothy $4: 7-8$ is particularly significant. Godliness here is quite clearly not seen as a state of reverence or as cultic worship. It needs to be continually worked at (present tense imperative) and, using the well known analogy of physical training drawn from athletics, spiritual discipline is encouraged with a clear notion of "fullness" also being highlighted: "godliness is valuable in every way, holding promise for both the present life and the life to come". This way of life holds the promise of fulfilment both in the present and also eschatologically. 1 Timothy 5:4 admittedly comes closest to the Greek concept of eusebeia as respect for the orders of life but this also reflects Hellenistic Jewish use of the concept. "For Paul, 'godliness' is the integration of the inward faith-commitment and outward faith-response that should characterize belief in God" (Towner 2006:339). In other words, godliness represents authentic Christian existence. In 1 Timothy 6:11 eusebeia, along with righteousness, faith, love, endurance and gentleness, is to be pursued as part of the lifelong process of being conformed to Christ so that one becomes a person of God. 2 Timothy 3:5 contrasts an outward form of godliness with true godliness which has transformative power.

This leaves 1 Timothy 2:2; 3:16; 6:3-6 and 2 Timothy 3:12. Clearly, given the paucity of this word group in the rest of the New Testament, this language is deliberately employed by the author to resonate with the cultural context. The question is whether this language merely reflects the social imaginary of the ancient world or whether it is designed deliberately to subvert it. 1 Timothy 3:16 is a good place to start. Here four terms associated with the Artemis cult are combined: "great", "mystery", "godliness" and "made manifest". In contrast to Ephesian spirituality, Christian existence is lived out (1 Tim 3:15) in the light of Christ's incarnation, resurrection and exaltation in a way which summons the world to response. Christology and missiology are combined to demonstrate that true devotion to Christ results inevitably in mission. This seems to me to be highly significant against the backdrop of the annual celebration of Artemis' birth at Ephesus and in that the Artemis cult was also highly mission oriented. ${ }^{21}$

In 1 Timothy 6:3-6 true teaching should result in authentic Christian existence and a mark of this "godliness" is contentment and not the desire to get rich. Given the association of eusebeia with devotion to Artemis in Ephesus, it is likely that this forms the background for this passage. In Acts

21 See Arnold (1989:20). 
19:23-25 it is specifically mentioned that devotion to Artemis creates wealth for Ephesian artisans. This, together with the huge value ascribed to magical books (Acts 19:19), suggests that Ephesian residents were well acquainted with the link between religious devotion and the means to gain wealth. The Pastor's insistence on contentment, by way of contrast, suggests that the "great gain in godliness" is a way of being in the world that effectively deals with any sense of loss of fullness. In Taylor's terminology the Pastor is effectively advocating contentment as that spirituality which occupies the routinized middle ground (2007:6-7).

In 2 Timothy 3:12 such contentment is clearly not complacency. The "godly life" is defined as "in Christ Jesus". The source of authentic Christian existence is Christ and this authentic existence is inevitably at odds with the way of life embraced as "piety" by pagans - whether in terms of allegiance to Artemis or to the imperial cult. However, the phrase "in Christ Jesus" also distinguishes this godliness from Jewish concepts; indeed the persecutions mentioned in Antioch, Iconium and Lystra all occurred at the instigation of "unbelieving Jews" (Acts 13-14). Three verses later the writer exhorts Timothy concerning the "sacred writings" (hiera grammata) which he has been instructed in since childhood. Although this phrase (with or without the article) occurs regularly in Philo and Josephus, ${ }^{22}$ this is the only occurrence in the New Testament. Indeed, hieros only occurs elsewhere at 1 Corinthians 9:13. The more usual term for Scripture, graphē, occurs in the very next verse (2 Tim 3:16). It seems to me that the writer deliberately uses the term hiera grammata here to contrast it with the Ephesia grammata. ${ }^{23}$

Returning to 1 Timothy $2: 2$ in the light especially of 2 Timothy $3: 12$ strongly suggests that the godliness being advocated is not conformity to the GraecoRoman concept of loyalty to moral order - it is not simply "good Christian citizenship". Furthermore, it cannot simply be equated with Hellenistic Jewish concepts of eusebeia, especially if Jewish syncretistic practices at Ephesus as outlined above are accepted. Instead it is an authentic spirituality consisting of knowledge of God (seen as faith in Christ) and its outworking in practical behaviour. Such commitment to Christ inevitably provokes persecution and, in the context of the threat of persecution, it is only natural to pray for a quiet and peaceful life. This can be illustrated by reference to some Dutch Anabaptist martyrs.

On 3 April 1575 a gathering of Dutch Anabaptists was discovered in a house near Aldgate in London. Seventeen were arrested and four

22 Philo, Migr. 139; Mos. 1.23; 2.290, 292; Spec. 2.159; 2.238; Praem. 79; Contempl. 28, 75, 78; Legat. 195; Josephus, A.J. 1.13; 3.178; 10.210; 16.168; C. Ap. 1.54; 1.229; B.J. 5.235.

23 Marshall (1999:109) entertains this possibility. 
subsequently imprisoned. On 22 July two were burned to death at Smithfield. Two letters from those imprisoned survive. The first is particularly interesting as it begins by echoing the language of 1 Timothy $2: 2$ - the very text that Dibelius highlighted as supporting his view of the Pastorals as advocating "the ideal of good Christian citizenship". The letter begins: "We poor and despised strangers, who are in persecution for the testimony of Jesus Christ, wish all men, of whatever race or office, from God, that the Lord would grant them a long peace, so that we may live in peace among one another, in all godliness, to the praise and glory of the Lord, and the salvation of the soul". ${ }^{24}$ The letter goes on to state, quoting 2 Timothy 3:12, "that those who have the true evangelical doctrine and faith will persecute no one, but will themselves be persecuted". ${ }^{25}$

\section{CONCLUSION}

The spirituality advocated in the Pastoral Epistles cannot simply be equated with "good Christian citizenship". Although at times (e.g. 1 Tim 5:4) eusebeia is used in a way which reflects wider Graeco-Roman concepts of piety, as I have also argued elsewhere ${ }^{26}$ this concept of "godliness" should be understood primarily against the background of reverence shown to Artemis at Ephesus and of that city as a centre for magical practice. In this context the Pastor employs the term deliberately to subvert the prevailing social imaginary. For the writer Christian eusebeia consists of devotion to Christ which involves behavioural change through the transformational process of conformity to Christ.

\section{BIBLIOGRAPHY}

AleXANDER, P.S. 2003. Sefer Ha-Razim and the Problem of Black Magic in Early Judaism. In: T.E. Klutz (ed.), Magic in the Biblical World: From the Rod of Aaron to the Ring of Solomon, (London: Continuum), pp. 170-90.

Arnold, C.E.

1989. Ephesians: Power and Magic. Cambridge: Cambridge University Press. SNTSMS 63.

BETZ, H.D. (ED.)

1992. The Greek Magical Papyri in Translation Including the Demotic Spells. Chicago: The University of Chicago Press. Second Edition.

24 Van Braght (1999:1012), my emphasis. This work was originally published in 1660.

25 Van Braght (1999:1013).

26 Pietersen (2004:140). 
Borgen, P., Fuglseth, K. \& Skarsten, R.

2005. The Works of Philo: Greek Text with Morphology. Bellingham: Logos Research Systems.

Dibelius, M. \& Conzelmann, H.

1972. The Pastoral Epistles. Philadelphia: Fortress. Hermeneia.

DunN, J.D.G.

1975. Jesus and the Spirit. London: SCM.

Foerster, W.

1971. Eusebēs, Eusebeia, Eusebeō. In: G. Kittel, G.W. Bromiley and G. Friedrich (eds), Theological Dictionary of the New Testament 7 (Grand Rapids: Eerdmans), pp. $175-85$.

GILL, M.

2008. Jesus as Mediator: Politics and Polemic in 1 Timothy 2:1-7. Oxford/New York: Peter Lang.

HORSLEY, G.H.R.

2006. New Documents Illustrating Early Christianity 4. Grand Rapids/Cambridge: Eerdmans.

LLEWELYN, S.R. \& KeARSLEY, R.A. 2007. New Documents Illustrating Early Christianity 6. Grand Rapids/Cambridge: Eerdmans.

MARSHALL, I.H. 1999. A Critical and Exegetical Commentary on the Pastoral Epistles. Edinburgh: T\&T Clark. ICC.

Niese, B.

1888. Flavii losephi Opera. Berolini: apvd Weidmannos.

OSTER, R.E. 1990. Ephesus as a Religious Center Under the Principate, I. Paganism Before Constantine. ANRW I/ 18(3):1661-1728.

Pietersen, L.K. 2004. The Polemic of the Pastorals: A Sociological Examination of the Development of Pauline Christianity. London: T \& T Clark. JSNTSup 264.

QuinN, J.D.

1990. The Letter to Titus. New York: Doubleday. AB 35.

TAYLOR, C.

2007. A Secular Age. Cambridge, Mass.: Belknap Press of Harvard University Press.

TOWNER, P.H.

2006. The Letters to Timothy and Titus. Grand Rapids/Cambridge: Eerdmans. NICNT. 
TREBILCO, P.

2004. The Early Christians in Ephesus from Paul to Ignatius. Tübingen: Mohr Siebeck. WUNT 166.

Van Braght, T.J.

1999. Martyrs Mirror. Scottdale. Herald.

WAAIJMAN, K.

2002. Spirituality: Forms, Foundations, Methods. Leuven: Peeters.

\section{LIST OF ABBREVIATIONS}

JOSEPHUS (from Niese [1888])
A.J.
Antiquitates judaicae
B.J.
Bellum judaicum
C. Ap.
Contra Apionem
PGM
Papyri Graecae Magicae (from Betz [1992])
PHILO
(From Borgen et al [2005])
Contempl.
De vita contemplativa
Legat.
Legatio ad Gaium
Migr.
De migratione Abrahami
Mos.
De vita Mosis
Praem.
De praemiis et poenis
Spec.
De specialibus legibus
TDNT
Theological Dictionary of the New Testament
Keywords
Trefwoorde
Pastoral Epistles
Pastorale briewe
Ephesus
Efese
Magic
Towerkuns
Artemis
Artemis
Godliness
Goddelikheid 